\title{
Comparative in situ hybridisation study of juvenile laryngeal papillomatosis in Papua New Guinea and Australia
}

\author{
R G Wright, D P Murthy, A C Gupta, N Cox, R A Cooke
}

\begin{abstract}
A comparative study of cases of juvenile laryngeal papillomatosis from Papua New Guinea $(\mathrm{n}=3)$ and Brisbane, Australia $(n=9)$ was carried out. In situ hybridisation reactions for human papillomavirus (HPV) types 6 and 11 occurred in 11 cases. All three cases from Papua New Guinea and eight from Australia gave positive signals. A negative reaction was observed in one Australian case. The intensity of the reaction was strong in seven cases, moderate in one, and weak in three. An equivocal reaction was also noted with probes for types 16 and 18 , and types 31,33 , and 35 in two cases from Australia and one from Papua New Guinea.

It is concluded that as similar staining patterns and intensities occurred in cases from both areas, the aetiology is the same. The equivocal reactions noted in three cases were probably due to cross hybridisation rather than multiple infection.
\end{abstract}

Juvenile laryngeal papillomatosis is part of a spectrum of diseases characterised by recurrent papillomata of the mucous membrane of the upper respiratory and food passages. The larynx is the site most often affected, and is often the only site. Lesions are frequently multiple and often recur even after radical treatment.

The condition is manifest clinically with progressive huskiness of the voice. Stridor and acute respiratory obstruction may occur late in the disease, necessitating tracheostomy. ${ }^{1}$ The incidence of papillomatosis is low, but its management is difficult because of its tendency for rapid recurrence.

A viral aetiology for laryngeal papillomatosis was first suggested in $1928 .^{2}$ Viral particles in the specimens have been shown electron microscopically. ${ }^{34}$ The presence of human papillomavirus (HPV) has been shown by immunofluorescence techniques, ${ }^{5}$ and HPV types 6 and 11 have been shown in papillomata by Southern blotting techniques with radioactive probes. ${ }^{6}$

In situ hybridisation with radioactive probes permits the identification and localisation in tissue of HPV subtypes. ${ }^{7}$ Recently this has also been accomplished with biotinylated probes, ${ }^{8}$ a rapid method suitable for routine laboratory use. A recent large series of adult and juvenile cases showed positive reactions for HPV types 6 and 11 in about two thirds of the cases studied. ${ }^{9}$ Another series of juvenile cases, however, showed $100 \%$ positivity for HPV types 6 and $11 .^{10}$

Juvenile laryngeal papillomatosis has been well documented in Papua New Guinea ${ }^{11}$ and in Australia. ${ }^{12}$ This study was carried out to evaluate in situ hybridisation reactions and to compare the prevalence of HPV types 6 and 11 in cases of juvenile laryngeal papillomatosis from both regions.

\section{Methods}

Paraffin wax embedded tissue from 12 cases diagnosed in Papua New Guinea $(\mathbf{n}=3)$ and Brisbane, Australia ( $\mathrm{n}=9$ ) was retrieved from the pathology files of the Department of Pathology, Faculty of Medicine, Port Moresby General Hospital, Papua New Guinea and the Department of Anatomical Pathology, Royal Brisbane Hospital. The clinical features of the 12 cases were sought and these are presented in table 1 . Most of these patients were female. Hoarseness of voice was the most common symptom. Multiple recurrent lesions and lesions at multiple sites were commonly observed.

Paraffin wax sections from formalin fixed tissues were cut at $5 \mu \mathrm{m}$ and placed on slides pretreated with 3-aminopropyltriethoxysilane. The in situ hybridisation was carried out using the HPV tissue hybridisation kit (Vira Type in situ; Life Technologies, IncBethesda Research laboratories, Gaithersburg, Maryland, USA). Biotinylated probes for HPV genotypes 6 and 11,16 and 18 and 31,33 , and 35 were used, with one section for each probe group.

The method entails partial denaturation of DNA (heating the sections at $100^{\circ} \mathrm{C}$ on metal trays in an oven following proteolytic digestion and application of the probes), incubation with hybridisation mixture (at $37^{\circ} \mathrm{C}$ for two hours), detection of hybridisation using a streptavidin alkaline phosphatase conjugate which binds to the biotin on the probe ${ }^{13}$ and dephosphorylation by alkaline phosphatase of the substrate 5-bromo-4-chloro-3 indolylphosphate (BCIP) in the presence of nitrobluetetrazolium (NBT). The reaction results in deposition of purplish blue precipitates at the sites of probe hybridisation to HPV DNA. ${ }^{14}$ The method described is based on 
Table 1 Cases of juvenile laryngeal papilloma studied by in situ hybridisation

\begin{tabular}{|c|c|c|c|c|c|c|c|}
\hline $\begin{array}{l}\text { Case } \\
\text { No }\end{array}$ & $\begin{array}{l}\text { At first } \\
\text { presentation }\end{array}$ & Sex & Country & $\begin{array}{l}\text { Clinical features at } \\
\text { first presentation }\end{array}$ & Site of papillomata & Treatment & Follow up \\
\hline 1 & 3 y $6 \mathrm{~m}$ & $\mathbf{F}$ & $\begin{array}{l}\text { Papua New } \\
\text { Guinea }\end{array}$ & $\begin{array}{l}\text { Progressive hoarseness of } \\
\text { voice and dyspnoea-3 } \\
\text { months }\end{array}$ & $\begin{array}{l}\text { Uvula, right tonsillar pillar; } \\
\text { tip of epiglottis, true and } \\
\text { false vocal cords, anterior } \\
\text { commissure; cricoaryte }\end{array}$ & $\begin{array}{l}\text { Initial tracheostomy. } \\
\text { Subsequent excision with } \\
\text { cupped forceps at } \\
\text { microlaryngoscopy }\end{array}$ & $\begin{array}{l}15 \text { months; } \\
\text { multiple } \\
\text { recurrences }\end{array}$ \\
\hline 2 & $5 y$ & $\mathbf{F}$ & $\begin{array}{l}\text { Papua New } \\
\text { Guinea }\end{array}$ & $\begin{array}{l}\text { Inability to talk clearly and } \\
\text { respiratory stridor-3 } \\
\text { months }\end{array}$ & False and true vocal cords & $\begin{array}{l}\text { Excision with cupped } \\
\text { forceps }\end{array}$ & $3 \mathrm{~m}$ \\
\hline 3 & 1 y $7 \mathrm{~m}$ & $\mathbf{M}$ & $\begin{array}{l}\text { Papua New } \\
\text { Guinea }\end{array}$ & $\begin{array}{l}\text { Progressively increasing } \\
\text { dyspnoea } 6 \text { months }\end{array}$ & $\begin{array}{l}\text { True and false vocal cords; } \\
\text { anterior commissures, } \\
\text { Trachea }\end{array}$ & $\begin{array}{l}\text { Initial tracheostomy } \\
\text { subseqent excision with } \\
\text { forceps }\end{array}$ & $6 \mathrm{~m}$ \\
\hline 4 & 7 y $7 \mathrm{~m}$ & $\mathbf{F}$ & Australia & $\begin{array}{l}\text { Increasing respiratory } \\
\text { distress, huskiness of } \\
\text { voice-6 months }\end{array}$ & $\begin{array}{l}\text { Vocal cords, epiglottis, } \\
\text { pharynx }\end{array}$ & $\begin{array}{l}\text { Initial tracheostomy } \\
\text { followed later by excision } \\
\text { with forceps }\end{array}$ & $3 y$ \\
\hline 5 & 9 y $6 \mathrm{~m}$ & $\mathbf{F}$ & Australia & $\begin{array}{l}\text { Hoarseness of voice; } \\
\text { recurrent laryngeal } \\
\text { papillomata since the age } \\
\text { of } 7 \mathrm{y}\end{array}$ & $\begin{array}{l}\text { Vocal cords, anterior } \\
\text { commissure, laryngeal } \\
\text { surface of epiglottis }\end{array}$ & Diathermy excision & 9 y $11 \mathrm{~m}$ \\
\hline 6 & $9 \mathrm{~m}$ & $\mathbf{F}$ & Australia & $\begin{array}{l}\text { Difficulty in breathing-3 } \\
\text { weeks, stridor; distress }\end{array}$ & True and false vocal cords & Diathermy excision & 1 y $8 \mathrm{~m}$ \\
\hline 7 & $2 y$ & $\mathbf{F}$ & Australia & $\begin{array}{l}\text { Vomiting, respiratory } \\
\text { stridor, hoarseness of } \\
\text { voice } 6 \text { months, noisy } \\
\text { breathing and difficulty- } \\
\text { since the age of } 5 \text { months }\end{array}$ & $\begin{array}{l}\text { Right and left vocal cords, } \\
\text { posterior pharyngeal wall } \\
\text { in hypopharynx }\end{array}$ & Multiple excisions & $5 \mathrm{~m}$ \\
\hline 8 & 4 y $6 \mathrm{~m}$ & $\mathbf{F}$ & Australia & Hoarseness of voice & False cords (right and left) & Multiple excisions & 1 y $7 \mathrm{~m}$ \\
\hline 9 & 1 y $6 \mathrm{~m}$ & $\mathbf{F}$ & Australia & $\begin{array}{l}\text { Huskiness of voice-1 } \\
\text { month }\end{array}$ & $\begin{array}{l}\text { Vocal cords (right and left) } \\
\text { Inferior surface of } \\
\text { epiglottis }\end{array}$ & Multiple excisions & 3 y $5 \mathrm{~m}$ \\
\hline 10 & 4 y $4 \mathrm{~m}$ & $\mathbf{F}$ & Australia & Hoarseness of voice & $\begin{array}{l}\text { Both vocal cords, posterior } \\
\text { pharyngeal wall, posterior } \\
\text { oesophageal wall }\end{array}$ & Multiple excisions & $1 \mathrm{y} 2 \mathrm{~m}$ \\
\hline 11 & 11 y $8 \mathrm{~m}$ & $\mathbf{M}$ & Australia & $\begin{array}{l}\text { Gradual onset of hoarseness } \\
\text { of voice }\end{array}$ & Both vocal cords & Excision & $5 y$ \\
\hline 12 & 6 y $6 \mathrm{~m}$ & $\mathbf{M}$ & Australia & $\begin{array}{l}\text { Hoarseness of voice-2 } \\
\text { years }\end{array}$ & $\begin{array}{l}\text { Vocal cords, pharyngeal } \\
\text { surface of arytenoid, } \\
\text { anterior commissure }\end{array}$ & Excision & 1 y $7 \mathrm{~m}$ \\
\hline
\end{tabular}

colorimetric in situ hybridisation techniques. ${ }^{81516} \mathrm{~A}$ positive control probe for human genomic DNA and a negative control probe for unrelated DNA sequences were used with each section tested.

The slides were examined by three of the authors (RGW, DPM, and NC) and the intensity of the positive signal was graded from weak $(+)$, moderate $(++)$, to strong $(+++)$. Any equivocal staining was regarded as negative. The tissue location of the positive signal was noted in each case. The slides were examined without prior knowledge of the origin of the tissue.

Table 2 Results of in situ hybridisation

\begin{tabular}{|c|c|c|}
\hline Case No & Country & $\begin{array}{l}\text { Reaction with probe for } \\
H P V \text { types } 6 \text { and } 11\end{array}$ \\
\hline $\left.\begin{array}{l}1 \\
2 \\
3\end{array}\right\}$ & Papua New Guinea & $\begin{array}{l}+ \\
+ \\
+++\end{array}$ \\
\hline $\left.\begin{array}{r}4 \\
5 \\
6 \\
7 \\
8 \\
9 \\
10 \\
11 \\
12\end{array}\right\}$ & Australia & $\begin{array}{l}+++ \\
+++ \\
++ \\
+++ \\
+++ \\
+ \\
+++ \\
+++\end{array}$ \\
\hline
\end{tabular}

\section{Results}

The reaction with the probe for HPV types 6 and 11 was found in 11 of the 12 cases studied (table 2). All three cases from Papua New Guinea and eight of the nine Australian cases gave positive signals. A negative reaction was observed in one Australian case. The reaction with the probe for HPV types 6 and 11 was present in the nuclei of the superficial epithelium in the positive cases (figure). No difference in the pattern of reaction of the probes was observed between the two groups of cases from the two regions. The intensity of the reaction was strong in seven cases, moderate in one case, and weak in three. An equivocal reaction was also noted with probes for types 16 and 18, and types 31,33 and 35 in three cases, two from Australia and one from Papua New Guinea.

\section{Discussion}

The results of the in situ hybridisation tests for HPV types 6 and 11 show similar patterns and intensity of staining in cases from both areas. The results obtained are in keeping with those reported from other areas. ${ }^{910}$ Quiney has speculated that variation in hybridisation reactions may be the result of variation in fixation of tissue rather than 


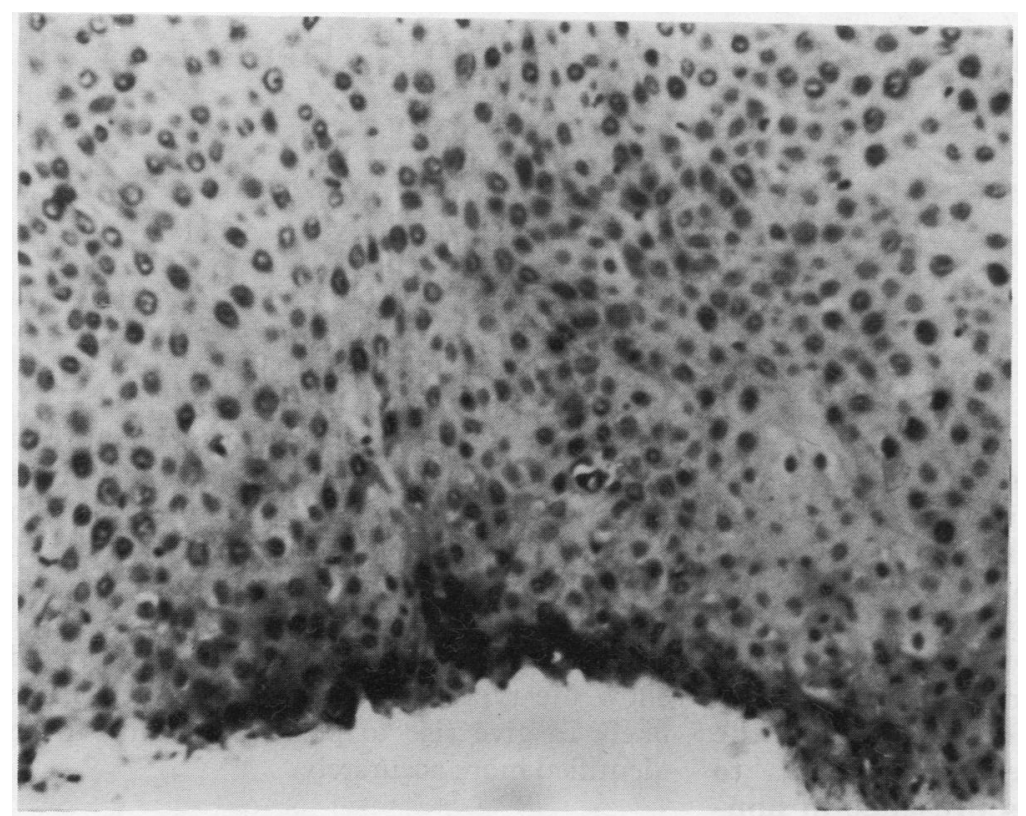

Positive staining for HPV types 6 and 11 in superficial cell nuclei of laryngeal papilloma. be due to this cross reactivity rather than to the presence of a multiple infection. We consider that caution in the interpretation of these reactions should prevail and support the methods of interpretation outlined by Quiney et al. ${ }^{9}$

1 Strong MS. Recurrent respiratory papillomatosis. Scot Brown's Otolaryngology. Vol 6. 5th edn. London: Butterworths, 1987:466-70.

2 Ullman EV. On the aetiology of laryngeal papilloma. Acta Otolaryngol 1928;5:317-38.

3 Incze JS, Lui PS, Strong MS, Vaughan CW, Clemente MP The morphology of human papillomas of the upper respiratory tract. Cancer 1977;39:1634-46.

4 Boyle WF, Rigos JI, Oshiro LS, Lennette EH. Electron microscopic identification of papova virus in laryngeal microscopic identification of papova virus

5 Steinberg B, Topp WC, Schneider O, Abramson A. Laryngeal papilloma virus infection during clinical remission. $N$ Engl J Med 1983;308:1262-4.

6 Gissman L, Wolnick L, Ikenburg $H$, et al. Human papilloma virus types 6 and 11 DNA sequences in genita and laryngeal papillomas and in some cervical cancers. Proc Natl Acad Sci USA 1983;80:560-3.

7 Gupta J, Gendelman HE, Naghasfar Z, et al. Specific identification of human papilloma virus type in cervical smears and paraffin sections by in situ hybridization with radioactive probes. Int J Gynecol Pathol 1985;4:211-8.

8 Lewis FA, Griffiths S, Dunicliff R, Wells M, Dudding N, Bird CC. Sensitive in situ hybridization technique using biotin-streptavidin-polyalkaline phosphatase. J Clin Pathol 1987;163:6.

attributable to geographical location. ${ }^{9}$ The results of this study support this hypothesis as there was no significant difference between the cases from the two regions investigated. From the results obtained juvenile laryngeal papillomatosis seems to have a similar aetiology in Papua New Guinea and Australia.

The equivocal reactions obtained with the probes for HPV types 16 and 18, and types 31, 33 , and 35 have not been previously reported. These can probably be explained by the nature of the detection. The Vira Type assay uses low stringency conditions to achieve higher sensitivity. This has been reviewed by Lorincz. ${ }^{17}$

The weak positive reaction with the probes for HPV types 16 and 18 and types 31, 33, and 35 was seen in three cases which were strongly positive for HPV types 6 and 11. As the stringency conditions allow a degree of cross hybridisation between closely related HPV types, these weak reactions were assumed to 